\title{
Transatlantica
}

Revue d'études américaines. American Studies Journal

Line Breaks in America: the Odds and Ends of Poetry

\section{Jane Ward, The Tragedy of Heterosexuality}

\section{Hugo Bouvard}

\section{(2) OpenEdition}

\section{Journals}

Electronic version

URL: https://journals.openedition.org/transatlantica/16610

DOI: 10.4000/transatlantica.16610

ISSN: $1765-2766$

\section{Publisher}

Association française d'Etudes Américaines (AFEA)

\section{Electronic reference}

Hugo Bouvard, "Jane Ward, The Tragedy of Heterosexuality", Transatlantica [Online], 1 | 2021, Online since 23 June 2021, connection on 01 February 2023. URL: http://journals.openedition.org/ transatlantica/16610 ; DOI: https://doi.org/10.4000/transatlantica.16610

This text was automatically generated on 1 February 2023.

\section{(c)}

Creative Commons - Attribution-NonCommercial-NoDerivatives 4.0 International - CC BY-NC-ND 4.0 https://creativecommons.org/licenses/by-nc-nd/4.0/ 


\title{
Jane Ward, The Tragedy of Heterosexuality
}

\author{
Hugo Bouvard
}

\section{REFERENCES}

Jane Ward, The Tragedy of Heterosexuality. New York City: NYU Press, Sexual Cultures, 2020. 207 pages. ISBN : 9781479851553 . $\$ 26.95$

1 A sociologist by training and a self-declared "white feminist dyke" (Ward, 2016 69), Jane Ward is Professor of Gender and Sexuality Studies at the University of California, Riverside. Her third book, The Tragedy of Heterosexuality is a personal yet scholarly account of "the contradiction and miseries of straight culture" (4). The ambition of the book is twofold: first, to provide a detailed and informed diagnosis of "straight suffering" (25); second, to alleviate this suffering by offering solutions to improve the lives of straight women and men, and, doing so, "redefin[ing] heterosexuality itself" (20). Lacking a formal introduction and conclusion, this short book gets "straight" to the heart of the matter: the first chapter lays out Ward's project and goals, while the fifth and last chapter goes beyond the diagnosis and offers a certain number of prescriptions to solve the problem at hand, namely the tragic contradictions that lie within heterosexual norms and make straight people's lives insufferable.

In chapter two, Ward begins her diagnosis of the "contradictions of straightness" (38). She identifies a "misogyny paradox," a catchphrase coined to refer to "men's simultaneous desire for and hatred of women" (33). The author traces the history of what she calls the "heterosexual-repair industry" in the United States, namely the "rehabilitative projects" that "capitalized" (38) on the aforementioned paradox by selling cultural artefacts aiming at improving opposite-sex romantic relationships. Ward successively looks at early-twentieth-century marriage manuals, midcentury campaigns advertising feminine hygiene products, and late-twentieth-century self-help books such as the international bestseller Men Are from Mars, Women are from Venus 
(Gray 1992), in order to show that heterosexual culture, far from being originally built on the mutual likeability of men and women, posits the irreconcilable differences of the two sexes. While mutual appreciation became an aspiration in the 1950s and has continuously gained cultural traction since, "marital misogyny," also known as “men's aversion to their wives" (56), nonetheless remained a staple of straightness. Through a close analysis of the advice contained in the books and advertising campaigns she studies, Ward insists on the tremendous amount of effort and labor that is expected of women in order to make their husbands like them, or at least tolerate them.

In chapter three, Ward pursues her investigation and turns to the contemporary "seduction industry." Drawing on interviews with and available videos of "seduction coaches" as well as her personal attendance of "two weekend-long seduction bootcamps" (31), the author ponders whether the seduction strategies taught to these straight men have any redeemable qualities, or if those can only increase the violence already experienced by straight women while dating. While Ward recognizes that the post-MeToo seduction industry has in part successfully rebranded itself as "feminist," promoting less coercive and more respectful pickup techniques than the ones she had observed a few years earlier, the author regrets that "the most effective strategies for getting straight men on board with profeminist, antirape messages is giving them space to celebrate their masculinity in the same breath" (106). Building upon her previous work, Ward pays close attention to the ways in which seemingly "straight" cultural practices, such as participating in these seduction bootcamps, actually function as cover-ups for homosocial bonding time. She offers insightful analyses of the way patriarchy sustains itself in the face of feminist critiques by rebranding itself as "softer" through neoliberal marketing interventions. Today, the seduction industry offers “an array of packaged services to monetize men's ability to seduce previously off-limits women by performing feminist empathy" (111), an instrumental approach that Wards describes as falling short of meeting her ideals of opposite-sex relationships.

4 In chapter four, Ward offers her readers an insight into how "radical queers" see straight people and what they think of heterosexual relationships. To do so, she draws on writings by queer activists and academics as well as on the responses to a short survey that she designed and posted on two of her social media accounts (Facebook and Twitter). The survey was directed at "queer-identified people in [her] extended social network" (120) to whom she asked two questions: "do you prefer the company of straight-identified people over queer-identified people [and] why or why not ?"; "Is there anything about straight people, or straight culture, that you find off-putting? Uncomfortable? Sad? Strange?" (120). Of the fifty-eight people who took the survey, only four responded no to both questions. The fifty-three other respondents described heterosexual relationships as "boring" (125), "sad" (127), "small," and "scripted" (140). Straight "rituals" such as baby showers and gender reveal parties are perceived as "bizarre," "off-putting," "not creative" (143-144). Straight men in particular are seen as "fragile," "self-centered," often "toxic" (133), and poor sexual partners to straight women. Chapter four thus functions as the nail in the heterosexual coffin: yet, it ends with a touch of optimism: "is it possible that heterosexuality [...] can rescue itself from its own tragic condition?" (154).

5 The shortest of the book, chapter five offers an answer to that question. Taking the opposite view to most lesbian feminist critiques of heterosexuality, Ward does not aim 
at dismantling or queering straightness, but hopes to "actualize" heterosexuality (157). This means helping straight people to live their sexual orientation to its fullest potential and become "deep heterosexuals." A "framework for honoring and preserving what straight people experience as fulfilling about hetero sex and straight culture" (159), deep heterosexuality is one of the "gifts" Wards claims she offers to straight men in her book. If both sexes are the intended audience of the project, the last chapter specifically targets straight men. As the author puts it, to become "authentically" or "deeply" straight, heterosexual men "need to learn to like women" (158). To do so, "one must be a feminist" (172). Drawing their inspiration from lesbians, straight men must "signal [...] an acute interest and investment in women's lives and accomplishments" (172). Sexually, men need to learn how to lust for a fuller range of women bodies, in particular those that fail to live up to the beauty standards set up by straight culture because they are fat, hairy, scarred and so on. In addition, men should not be attracted to these bodies in spite of these characteristics but because of them: their attractiveness should be triggered by men's identification with women's "temperaments" and lived "experiences" (172).

6 The Tragedy of Heterosexuality is a compelling and highly entertaining book. It benefits from a very straightforward style and witty sense of humor. While infused with decades of queer and lesbian feminist scholarly and activist interventions, Ward's writing never relies on jargon, remaining accessible to a wide audience. Through funny punchlines, clever aphorisms, and even neologisms such as "heteroresignation" (162), the lexical inventiveness she displays is commendable. Moreover, Ward's hallmark is her ability to break away with preconceptions and completely flip the perspective. Under her pen, it is heterosexuality, not queerness, that is worrisome because of its "emotional flatness" and its "antiflamboyance" (116). Not merely a sexual orientation, straightness is instead "a fetish for normalcy" and queerness "a desire for the unexpected and counternormative" (15). Homophobia has little to do with queer people: it is the "outward expression of heterosexual misery," "a kind of subconscious rage against the gendered and sexual possibilities that lie beyond the violence and disappointments of straight culture" (115).

7 Claiming "love and empathy as core elements" of her approach, Ward indeed never looks down on straight people, even as she enumerates all the reasons why she thinks they are collectively miserable. She shows evidence of a great amount of reflexivity, in particular in chapter 3 when she details the ambivalent feelings that assail her as she attends a seduction bootcamp: "anger" and "repulsion" for men's misogyny, but also "optimism" (94) about their potential to actually care for women. While the book was born "out of solidarity" for straight women, and even though the author could easily have dismissed or derided heterosexual men, she realized that the bond that she shares with them, namely "a desire to partner with women" (155), is strong enough for her to direct all efforts towards them in the last chapter of the book. Last but not least, Ward's approach is truly intersectional as it systematically questions the role of race, racism and white supremacy in the phenomena the book tackles: for instance, the author shows in chapter three how the seduction industry lures straight men from different racial and ethnic backgrounds with the promises of a greater access to white women and a "cross-racial and cross-national solidarity and 'love' among men" (109).

8 This thought-provoking book could have benefited from a slightly more rigorous contextualization. There is a certain vagueness about the process of collecting and 
selecting materials (the number of interviews that Jane Ward conducted with seduction coaches, for instance, is not specified). There also is a certain superficiality in the ways in which these materials are showcased, particularly in chapter four where survey responses are somewhat illustrative rather than the basis of an analysis that considers the social characteristics of the respondents. Finally, the author could have strengthened her argument in chapters two and three by questioning the actual reception of the marriage manuals and seduction videos discussed. As such, her analysis implicitly relies on the "strong effects" that these cultural artefacts have on their recipients, whereas cultural sociologists have highlighted the agency and the active role undertaken by consumers of these products. Despite those reservations, however, this book is another foundational work in the field of critical heterosexual studies and will likely be an important staple of many gender and sexuality courses.

\section{BIBLIOGRAPHY}

GRAY, John. Men Are from Mars, Women are from Venus: The Classic Guide to Understanding the Opposite Sex. New York: HarperCollins Publishers, 1992.

\section{AUTHORS}

\section{HUGO BOUVARD}

Institut de Recherche Interdisciplinaire en Sciences Sociales (UMR 7170) 